\title{
Mental health problems of homeless children and families: longitudinal study
}

\author{
Panos Vostanis, Eleanor Grattan, Stuart Cumella
}

\begin{abstract}
Objective: To establish the mental health needs of homeless children and families before and after rehousing.

Design: Cross sectional, longitudinal study.

Setting: City of Birmingham.

Subjects: 58 rehoused families with 103 children aged 2-16 years and 21 comparison families of low socioeconomic status in stable housing, with 54 children.

Main outcome measures: Children's mental health problems and level of communication; mothers' mental health problems and social support one year after rehousing.

Results: Mental health problems remained significantly higher in rehoused mothers and their children than in the comparison group (mothers $26 \%$ v $5 \%, \mathrm{P}=0.04$; children $39 \%$ v 11\%, $\mathrm{P}=0.0003$ ). Homeless mothers continued to have significantly less social support at follow up. Mothers with a history of abuse and poor social integration were more likely to have children with persistent mental health problems. Conclusions: Homeless families have a high level of complex needs that cannot be met by conventional health services and arrangements. Local strategies for rapid rehousing into permanent accommodation, effective social support and health care for parents and children, and protection from violence and intimidation should be developed and implemented.
\end{abstract}

\section{Introduction}

Following research on the health problems of single adult homeless people, there has been interest in the characteristics and needs of homeless children and their families, who constitute a different and rapidly growing population. ${ }^{1}$ At any one time, at least 60000 families, with between 140000 and 170000 children, are defined as homeless by local authorities in England. ${ }^{23}$ In addition, the number of single homeless teenagers living on the streets is increasing, as is the number of homeless families living with friends and relatives or in squats.

The causes of homelessness in this group are diverse: many are victims of domestic violence, ${ }^{4}$ and the group also includes refugee families, mainly in the London area. ${ }^{5}$ Homeless children are significantly more likely than the general population, or comparison children in stable housing, to have delayed development, ${ }^{6}$ learning difficulties, ${ }^{7}$ and higher rates of mental health problems (behavioural problems such as sleep disturbance, eating problems, aggression, and overactivity, and emotional problems such as depression, anxiety, and self harm). ${ }^{6-10}$ Such problems are not specific to homeless families. They occur in other families living in adversity and have been found to be related to adverse life events that precipitate homelessness-for example, family breakdown, abuse, exposure to domestic violence, and poor social networks. ${ }^{10}$

Because many homeless families have changed address frequently or urgently, they are less likely than the rest of the population to be registered with a general practitioner.This reduces their access to primary and secondary medical care, as well as to immunisations and other preventive health procedures. Homeless families therefore tend to rely on accident and emergency departments for medical treatment, and they have high rates of hospital admission. ${ }^{11}$ To date, there has been no research on the long term impact of homelessness on the mental health of children and their families. This cross sectional longitudinal study was designed to establish the extent of mental health problems among homeless children and their parents one year after rehousing by the local authority.

\section{Subjects and methods}

\section{Subjects}

Subjects were selected from a sample described in an earlier cross sectional study on homeless families. ${ }^{10}$ This included 113 homeless families who had applied for rehousing to the City of Birmingham's housing department and who had been admitted to the seven homeless centres managed by the department over one year. These were initially interviewed within two weeks of becoming homeless and being admitted to the hostel. A comparison group of 29 housed, low income families had been selected from two schools where homeless children attended at the time, by random selection from the school list. All families were of socioeconomic class $\mathrm{V}^{12}$ A relatively small comparison sample was selected because of the expected "homogeneity" (low variance of family and social variables) in a stable community population. Parents were asked to give informed consent, after approval by two local research ethics committees.

Our study was conducted one year after the initial assessment of both groups. Homeless families had already given consent to be contacted at follow up, and their new address was sought from the housing department. Although only seven families $(6 \%)$ refused to be interviewed again at this stage, a substantial proportion (40 families, 35\%) had already moved from their follow up address and were untraceable, and $8(7 \%)$ had left the centre before being rehoused by the local authority. At one year, we interviewed 58 families (51\% of initial sample) with 103 children aged 2-16 years who were in housing and constituted the study group, and 21 comparison families $(72 \%$ of initial sample) with 56 children aged 2-16 years. Families lost to follow up did not differ from those interviewed at one year in regard to family composition, demographic factors, or reasons for becoming homeless. Children younger than 2 years were not included because there is no reliable way of establishing
Department of Child and Adolescent

Psychiatry,

University of Birmingham, Parkview Clinic, Moseley, Birmingham B13 8QE

Panos Vostanis, senior lecturer in child and adolescent psychiatry

Department of Psychiatry, Queen Elizabeth

Psychiatric Hospital, Edgbaston, Birmingham B15 2QZ

Eleanor Grattan, research associate Stuart Cumella, senior research fellow

Correspondence to: Dr Vostanis

BMJ 1998;316:899-902 
behavioural and emotional problems for such a young age group. Because of the small number of fathers involved at intake ${ }^{10}$ and follow up (table 1), data analysis was confined to mothers. All comparison families interviewed at follow up had remained in the same residence over the 12 month period.

\section{Assessment}

Five research instruments were used to assess mental health problems.

Semi-structured interview with the mother-this consisted of questions concerning house moves, family life, peer and family relationships, and behavioural problems among the children. Mothers were interviewed at the hostel by a research psychologist (EG).

Child behaviour checklist-this questionnaire has been widely used in research to measure externalising (behavioural) and internalising (emotional) problems, and social competence (activities, peer relationships, and school performance) in children. ${ }^{13}$ It has been standardised in large community and clinical populations. Adapted scores ( $\mathrm{T}$ scores) indicate whether the child is within the "clinical range" (problem of sufficient severity to be referred for treatment to a child mental health service: $\mathrm{T}$ score $\geqslant 63$ ) or within the "social maladjustment" range (T score $\leqslant 37$ ). A parent completed a separate questionnaire for each child in the survey. In the case of children aged 2-3 years, the version used excluded social competence questions. ${ }^{14}$

General health questionnaire-this is an established and standardised screening questionnaire for use in surveys of adult mental health problems in the general population. ${ }^{15}$ A 28 -item version was used in this study, which generates scores for somatic symptoms, anxiety, social dysfunction, and depression. Cut off scores have been established to identify possible mental health disorders (caseness). A questionnaire was completed by each mother.

Interview schedule for social interaction-this is a measure of people's social network. ${ }^{16}{ }^{17}$ It includes scales that measure the availability and perceived adequacy of attachment relationships, the availability and perceived adequacy of social integration, and the number of attachment relationships with whom the respondent has recently been having rows or unpleasant interaction with. ${ }^{17}$

Table 1 Characteristics of homeless families (one year after rehousing) and of low income families in stable housing

\begin{tabular}{|c|c|c|c|}
\hline Characteristic & Rehoused ( $n=58$ ) & Comparison $(\mathrm{n}=21)$ & Difference \\
\hline No (\%) single mothers & $40(69)$ & $7(33)$ & \multirow{2}{*}{$\chi^{2}=21.2, P<0.001$} \\
\hline No $(\%)$ two parent families & $18(31)$ & $14(66)$ & \\
\hline Median (range) No of children & $2(1-5)$ & $3(1-7)$ & $t=1.1, \mathrm{NS}$ \\
\hline Mean (range) age of mother (years) & $31(20-44)$ & $32.4(26-46)$ & $t=1.1, \mathrm{NS}$ \\
\hline Mean (range) age of children (years) & $8.5(3-16)$ & $9.4(3-16)$ & $t=1.7, \mathrm{NS}$ \\
\hline No (\%) boys & $54(52)$ & $28(52)$ & $\chi^{2}=0.005, \mathrm{NS}$ \\
\hline \multicolumn{4}{|l|}{ Mother's ethnic group: } \\
\hline White & $48(83)$ & $14(67)$ & \multirow{3}{*}{$\chi^{2}=7.7, P=0.02$} \\
\hline Afro-Caribbean & $6(10)$ & $2(10)$ & \\
\hline Asian & $4(7)$ & $5(24)$ & \\
\hline \multicolumn{4}{|l|}{ Mother's occupation: } \\
\hline Unemployed & $47(81)$ & $14(67)$ & \multirow{4}{*}{$\chi^{2}=6.5, \mathrm{NS}$} \\
\hline Full time work & $1(2)$ & $2(10)$ & \\
\hline Part time work & $7(12)$ & $5(24)$ & \\
\hline Full time education & $3(5)$ & 0 & \\
\hline
\end{tabular}

Communication domain of the Vineland adaptive behaviour scales-this measures the development of communication in children. ${ }^{18}$ Scores are adapted according to norms from the general population; an age equivalent score is provided and indicates the chronological age at which the child is functioning.

\section{Statistical analysis}

Within the homeless group, mental health scores at the first and follow up assessment were compared by Wilcoxon matched pairs, signed ranks test. Betweengroup analyses (homeless and comparison families) were done with $\chi^{2}$ test, $t$ test, and Mann-Whitney nonparametric $\mathrm{U}$ test, depending on the nature and distribution of the data.

\section{Results}

\section{Family characteristics and housing}

Family characteristics are presented in table 1. Because hostels for homeless Asian and Afro-Caribbean families were run by the voluntary sector and were not included in the initial study, ethnic minority groups were underrepresented in the rehoused group in comparison with both the housed group $\left(\chi^{2}=7.7, \mathrm{df}=2\right.$, $\mathrm{P}=0.02$ ) and the local general population (inner Birmingham wards have up to $12.5 \%$ Afro-Caribbean and $43 \%$ Asian children). At the time of the first assessment, ${ }^{10}$ the most common reason for becoming homeless was to escape from violence, either by a partner or ex-partner $(29,50 \%)$ or by neighbours $(20,35 \%)$. Other families had become homeless after eviction from their previous housing because of mortgage or rent arrears $(3,5 \%) ; 6(11 \%)$ had left voluntarily or for other reasons.

The average length of stay in the homeless centre for the families who were reinterviewed was 10 weeks (range 2-58 weeks). The housing department's target is to rehouse within 28 days. Thirty five families $(60 \%)$ moved to the first property offered. At follow up, 17 families $(30 \%)$ had moved at least once in the year and $9(16 \%)$ had been homeless again at some time. Of those who had moved since being rehoused, 29 (50\%) gave violence or harassment from an ex-partner or neighbours as the reason for their move. Seventeen families $(30 \%)$ were unhappy with the property they had been allocated, and $20(35 \%)$ were not happy with the area. At follow up, 52 families (90\%) lived in rented property, two $(3 \%)$ in owned property, three $(5 \%)$ in a homeless centre, and one family (2\%) was lodging with friends. Eighteen comparison families $(81 \%)$ lived in rented property and four $(22 \%)$ in owned property $\left(\chi^{2}\right.$ for difference $\left.=6.5, \mathrm{df}=3, \mathrm{P}=0.09\right)$.

\section{Mental health problems}

\section{Mothers}

Homeless mothers had high rates of previous abuse $\left(25(43 \%) v 1(5 \%)\right.$ control mother, $\left.\chi^{2}=10.6, \mathrm{P}=0.001\right)$. On the basis of general health questionnaire scores, the rate of homeless mothers who reported mental health problems of clinical significance had decreased from $52 \%$ at initial interview to $26 \%$ at one year follow up, and total scores significantly decreased for the homeless group $(P=0.002$, Wilcoxon test $)$. However, at follow up the scores remained significantly higher than 
those of comparison mothers (table 2) or the general population (up to $20 \%$ for women of this age group). ${ }^{19}$

\section{Children}

Seven children had been in care before becoming homeless and two since rehousing. Twelve children had been placed on the at risk child protection register before they became homeless, and six since being rehoused; 10 children had a history of physical or sexual abuse. No comparison children were reported to have had similar adversities.

Though homeless children improved on the Vineland communication scores, this did not reach statistical significance $(\mathrm{P}=0.07$, Wilcoxon test), and they remained significantly more delayed than children in the comparison group (table 2). Homeless children's age equivalent of communication remained significantly lower than their chronological age (age equivalent 7.8 years $v$ chronological age 8.5 years; $\mathrm{P}=0.0001$ ), unlike controls (age equivalent 9.1 years $v$ chronological age 9.4 years; $\mathrm{P}=0.16$ ). Homeless children's scores on the child behaviour checklist showed no significant change (58.2 at baseline $v 59.2$ at follow up; $\mathrm{P}=0.53$ ), and they remained significantly more likely to be within the clinical range than the comparison group.

\section{Discussion}

Most research on homeless people has focused on populations of single adults. This study highlights the high level of mental health needs among homeless children and their mothers. Homeless families constitute a relatively heterogenous population with complex health, social, and educational problems, which often precipitate the episode of homelessness. These are related to underlying psychosocial factors, and are likely to persist, even after rehousing.

The risk of mental health problems in children was not accounted for by socioeconomic deprivation, as they differed significantly from the comparison group on several measures. However, differences could be explained by confounding factors such as family and social stability (for example, there were fewer single parents in the comparison group). In contrast, residential, social, and family instability remained for a substantial proportion of homeless families, who thus re-entered a similar cycle of disruption. Residential instability was reflected in the percentage of families lost to follow up, as the local authority (housing, education, or social services) had no official record of them once they had moved from the first residence offered by the city council. Even after rehousing, children remained vulnerable to several risk factors, such as family breakdown, domestic violence, maternal mental health disorders, learning and developmental difficulties and delays, and loss of peer relationships.

These families do not fit into traditional public health and welfare systems. ${ }^{20}$ There are no designated healthcare services for homeless families, and there is often little interagency coordination, with managers and policy makers often responding to different definitions of need and statutory obligations. ${ }^{21}$ Some services have attempted to coordinate the care of homeless families and to provide support (and occasionally direct treatment) in a relatively structured
Table 2 Mental health problems in mothers and children at one year follow up. Values are numbers (percentages) unless specified otherwise

\begin{tabular}{|c|c|c|c|}
\hline & $\begin{array}{l}\text { Rehoused } \\
\text { group }\end{array}$ & $\begin{array}{l}\text { Comparison } \\
\text { group }\end{array}$ & Difference ${ }^{*}$ \\
\hline Mothers & $(n=58)$ & $(n=21)$ & \\
\hline \multicolumn{4}{|l|}{ General health questionnaire: } \\
\hline Caseness† & $15(26)$ & $1(5)$ & $\chi^{2}=4.3, P=0.04$ \\
\hline Mean (SD) total score & $29.9(16.5)$ & $18.1(9.6)$ & $\mathrm{Z}=2.9, \mathrm{P}=0.004$ \\
\hline \multicolumn{4}{|l|}{ Interview schedule for social interaction: } \\
\hline Availability of attachment relationships & $4.7(2.2)$ & $7.1(1.1)$ & $\mathrm{z}=4.3, \mathrm{P}<0.0001$ \\
\hline Perceived adequacy of attachment relationships & $7.1(3.7)$ & $10.6(1.1)$ & $\mathrm{z}=3.6, P=0.0003$ \\
\hline Availability of social integration & $7.0(3.2)$ & $10.7(4.6)$ & $\mathrm{z}=3.3, \mathrm{P}=0.0008$ \\
\hline Perceived adequacy of social integration & $10.4(4.8)$ & $13.9(2.1)$ & $z=2.8, P=0.005$ \\
\hline Children & $(n=103)$ & $(n=54)$ & \\
\hline \multicolumn{4}{|l|}{ Child behaviour checklist: } \\
\hline Caseness & $40(39)$ & $6(11)$ & $\chi^{2}=12.9, P=0.0003$ \\
\hline Social maladjustment $\ddagger$ & $71(69)$ & $33(61)$ & $\chi^{2}=3.7, P=0.05$ \\
\hline Mean (SD) score & $59.2(8.7)$ & $49.2(9.1)$ & $\mathrm{z}=5.8, \mathrm{P}<0.0001$ \\
\hline Mean (SD) internalising & $55.1(12.1)$ & $49.4(9.3)$ & $\mathrm{Z}=2.8, \mathrm{P}=0.005$ \\
\hline Mean (SD) externalising & $59.1(10.5)$ & $50.4(9.9)$ & $\mathrm{Z}=4.7, P<0.0001$ \\
\hline \multicolumn{4}{|c|}{ Vineland adaptive behaviour scales-communication domain: } \\
\hline Mean (SD) standard score & $88.2(15.2)$ & $95.2(9.8)$ & $\mathrm{Z}=2.3, \mathrm{P}=0.02$ \\
\hline Mean (SD) age equivalent & $7.8(3.2)$ & $9.1(2.9)$ & $\mathrm{Z}=2.7, \mathrm{P}=0.006$ \\
\hline
\end{tabular}

${ }^{\star}$ Results from $\chi^{2}$ test or Mann-Whitney U test.

†Possible mental health disorder, or rate of psychiatric morbidity.

$\ddagger$ Social functioning below expected population norms

way. Such projects include the provision of advocacy services, space for children to play and parents to meet, health visiting, input from general practitioners, social work, and input from community psychiatric nurses and community midwives. ${ }^{322}$ The voluntary sector has also developed services covering hostels for homeless families. Although three major reports on the health and educational needs of homeless children and their families have been published in Britain, ${ }^{3623}$ few of their key recommendations have been implemented; if they have, this has been done in isolation, without setting up local or national standards.

Housing, education, health, and police services in each district need to establish a coordinating group to review the needs of homeless families, with the aim of developing and implementing a local strategy to facilitate rapid rehousing into permanent accommodation, effective social support and health care for parents and children, and protection from violence and intimidation. Central government and local housing authorities need a clear policy commitment to provide rapid and permanent rehousing for homeless families, to

\section{Key messages}

- Homeless children and their mothers have a high level of mental health problems

- Homeless families experience many risk factors, such as domestic violence, abuse, and family and social disruption

- In two fifths of children and a quarter of mothers, mental health problems persisted after rehousing

- In contrast with a comparison group of families of low socioeconomic status, a substantial proportion of homeless families remained residentially and socially unstable 
minimise the risk of personal and family breakdown. New service models will require evaluation.

We thank all families who kindly participated in the study. We are grateful to the Housing Department of the Birmingham City Council, Mrs Daphne Agnew, the staff of the seven hostels, the head teachers of the schools involved in the selection of the comparison sample, and $\mathrm{Mr}$ Saeed Haque for the statistical advice.

Contributors: PV participated in the formulation of the study hypothesis, research design, data analysis and writing of the paper and is the guarantor of the paper. EG completed data collection and participated in data analysis and writing of the paper. SC participated in the formulation of the study hypothesis, research design, data analysis, and writing of the paper.

Funding: Nuffield Foundation.

Conflict of interest: None.

1 Bhugra TS, ed. Homelessness and mental health. Cambridge: Cambridge University Press, 1996.

2 Leff J. All the homeless people-where do they all come from? BMJ 1993;306:669-70.

3 Connelly J, Crown J, eds. Homelessness and ill health:report of a working party of the Royal College of Physicians. London: Royal College of Physicians, 1994

4 Thomas A, Niner P. Living in temporary accommodation: a survey of homeless people. London: HMSO, 1989.

5 Brooks L, Patel M. Homelessness and health: a right to health care, a challenge for the health services. London: Redbridge and Waltham Forest Health Authority, 1995.

6 Conway J, ed. Prescription for poor health: the crisis for homeless families. London: LFC, Maternity Alliance, SHAC, Shelter, 1988.

7 Finkelstein J, Parker R. Homeless children in America: taking the next step. Am J Dis Child 1993;147:520-1.
8 Amery J, Tomkins A, Victor C. The prevalence of behavioural problems amongst homeless primary school children in an outer London borough. Public Health 1995;109:421-4.

9 Vostanis P, Cumella S, Briscoe J, Oyebode F. Psychosocial characteristics of homeless children: a preliminary study. Eur J Psychiatry 1996;10: 108-17.

10 Vostanis P, Cumella S, Grattan E. Psychosocial functioning of homeless children. J Am Acad Child Adol Psychiatry 1997;36:881-9.

11 Victor C, Connelly J, Roderick P, Cohen C. Use of hospital services by homeless families in an inner London health district. BMJ 1989;299: 725-7.

12 Office of Population Censuses and Surveys. Classification of occupations 1980. London: HMSO, 1980.

13 Achenbach T. Manual for the child behaviour checklist/4-18 and 1991 profile. Burlington, VT: University of Vermont, 1991.

14 Achenbach T. Manual for the child behaviour checklist/2-3 and 1992 profile. Burlington, VT: University of Vermont, 1992.

15 Goldberg D. Manual of the general health questionnaire. Windsor: NFER Nelson, 1978.

16 Henderson S, Duncan-Jones P, Byrne D, Scott J. Interview schedule for social interaction. Canberra: Academic Press, 1981.

17 Henderson S, Byrne D, Duncan-Jones P. Neurosis and the social environment. Canberra: Academic Press, 1980.

18 Sparrow S, Bella D, Cicchetti D. Vineland adaptive behaviour scales. Circle Pines, MN: American Guidance Services, 1984.

19 Goldberg D, Huxley P. Common mental disorders: a bio-social model. London: Tavistock, 1992.

20 Heath I. The poor man at his gate: homelessness is an avoidable cause of ill health. BMJ 1995;309:1675-6.

21 Stewart G, Stewart J. Social work with homeless families. Br J Soc Work 1992;22:271-89.

22 Hammond L, Bell J. The setting up of a drop-in service to a homeless families project. Association of Child Psychology and Psychiatry Newsletter $1995 ; 17: 132-8$.

23 Power S, Whitty G, Youdell D. No place to learn: homelessness and education. London: Shelter, 1995.

(Accepted 27 November 1997)

\title{
Rate of recurrent collapse after vaccination with whole cell pertussis vaccine: follow up study
}

\author{
Patricia E Vermeer-de Bondt, Jerry Labadie, Hans C Rümke
}

Editorial by Miller

Laboratory for

Clinical Vaccine

Research, Nationa

Institute of Public

Health and

Environment, PO

Box 1,3720 BA

Bilthoven,

Netherlands

Patricia E

Vermeer-de Bondt,

child health

consultant

Jerry Labadie,

clinical investigator

Hans C Rümke,

paediatrician-

epidemiologist

Correspondence to:

Dr Vermeer-de

Bondt

patricia.vermeer@

rivm.nl

BMJ 1998;316:902-3
Whole cell vaccines against pertussis can induce a hypotonic-hyporesponsive episode or shock-like syndrome (collapse) in children, ${ }^{1}$ but this may also occur with diphtheria and tetanus vaccines, acellular pertussis vaccine, and without vaccination. ${ }^{2}$ Two prospective studies estimated that the rate of collapse after vaccination was considerable (13 out of 35284 and 9 out of 15 752). ${ }^{3}{ }^{4}$ The only follow up study, which assessed a small series, was inconclusive about sequelae. ${ }^{5}$

Comparing the rates of collapse between countries poses problems because of differences in vaccination schedules and vaccines and in the way adverse reactions are monitored and symptoms reported. Moreover, case definitions are inconsistent.

Although the rate of recurrent collapse after whole cell pertussis vaccine has not been studied, for over 30 years repeat doses of vaccine have been contraindicated in children who experience a collapse reaction. Before 1993, in both the Netherlands and the United States children who had had a collapse reaction after vaccination with whole cell pertussis were not given a repeat dose. This contraindication still applies in the Netherlands, although most children are given further doses. We measured the numbers of cases of collapse in children after vaccination with whole cell pertussis vaccine in the Netherlands in 1994 and followed up all cases who were reported after their first dose.

\section{Subjects, methods, and results}

In the Netherlands over $99 \%$ of childhood vaccines are administered routinely by specialised staff within a child health clinic. All vaccinations are registered in provincial databases, so that data are accessible to medical staff if a child changes address. In 1962 an enhanced passive surveillance system for monitoring adverse events following vaccinations, with a 24 hour telephone service, was instigated. Some degree of underreporting is inevitable, but it seems to be limited and not biased against collapse (our laboratory's year report, 1994). Collapse is defined as sudden loss of muscle tone, pallor, and unresponsiveness. Sometimes symptoms are incomplete or atypical. When only one of the symptoms is present, the event is logged as an unspecified minor illness and not collapse.

In 1994, 712 adverse events were reported to the surveillance system, 587 after combined vaccination against diphtheria, tetanus, pertussis, and poliomyelitis (DTP-IPV vaccine) and Haemophilus influenzae type B (Hib-PRP-T vaccine). (The adverse events from $\mathrm{H}$ influenzae type $\mathrm{B}$ vaccine are infrequent and mild and not dealt with here.) After verification of symptoms we diagnosed 134 collapses (table).

In 1996 we followed up the 105 children with collapse reported after their first vaccinations. Detailed 